\title{
Using Low-Cost Iron-Based Materials as Oxygen Carriers for Chemical Looping Combustion
}

\author{
E. Jerndal ${ }^{1 *}$, H. Leion', L. Axelsson', T. Ekvall', M. Hedberg', K. Johansson', M. Källén', \\ R. Svensson ${ }^{1}$, T. Mattisson ${ }^{2}$ and A. Lyngfelt ${ }^{2}$ \\ 1 Chalmers University of Technology, Department of Chemical and Biological Engineering, \\ Division of Environmental Inorganic Chemistry, 41296 Göteborg - Sweden \\ 2 Chalmers University of Technology, Department of Energy and Environment, Division of Energy Technology, 41296 Göteborg - Sweden \\ e-mail: erik.jerndal@chalmers.se - leion@chalmers.se - lovaxe@student.chalmers.se - ekvallt@student.chalmers.se - marhed@student.chalmers.se \\ kristofj@student.chalmers.se - kallen@student.chalmers.se - sverob@student.chalmers.se -tm@chalmers.se - anders.lyngfelt@chalmers.se \\ * Corresponding author
}

Résumé - Utilisation de matériaux bon marché à base de fer comme transporteur d'oxygène dans la combustion en boucle chimique - Pour appliquer la combustion en boucle chimique à des charges solides, il est important d'utiliser des matériaux transporteurs d'oxygène bon marché. En effet, la durée de vie du transporteur d'oxygène risque d'être plus courte sur charge solide que sur charge gazeuse. Ces matériaux doivent également bien convertir le monoxyde de carbone et l'hydrogène résultant de la gasification, tout en étant suffisamment durs pour résister à la fragmentation. Plusieurs matériaux ont montré un potentiel de conversion élevé sur le gaz de synthèse ainsi qu'une résistance mécanique élevée, ce qui permet d'envisager leur utilisation lors des développements futurs de la technologie. Parmi ces matériaux, on trouve des oxydes en copeaux provenant de Sandvik et Scana, et un minerai de fer de LKAB. Tous les matériaux testés ont permis d'atteindre des conversions plus élevées sur gaz de synthèse que le matériau de référence (ilménite) utilisé au cours de l'étude. D’une manière générale, les transporteurs d'oxygène les moins résistants, sans doute les plus poreux, sont les plus réactifs avec le gaz de synthèse. Le taux de conversion du CO obtenu avec ces matériaux est toujours plus élevé qu'avec l'ilménite. Le taux de conversion de l'hydrogène est plus élevé lorsque la durée de réduction augmente. Le matériau Sandvik 2 a permis d'atteindre les taux de conversion les plus importants sur gaz de synthèse et a donc été sélectionné pour des tests sur charge solide. Le taux de conversion sur charge solide avec ce matériau est plus élevé qu'avec l'ilménite.

\footnotetext{
Abstract - Using Low-Cost Iron-Based Materials as Oxygen Carriers for Chemical Looping Combustion - In chemical looping combustion with solid fuels, the oxygen-carrier lifetime is expected to be shorter than with gaseous fuels. Therefore, it is particularly important to use low-cost oxygen carriers in solid fuel applications. Apart from being cheap, these oxygen carriers should be able to convert the $\mathrm{CO}$ and $\mathrm{H}_{2}$ produced from the solid fuel gasification and be sufficiently hard to withstand fragmentation. Several low-cost iron-based materials displayed high conversion of syngas and high mechanical strength and can be used for further development of the technology. These materials include oxide scales from Sandvik and Scana and an iron ore from LKAB. All tested oxygen carriers showed higher gas conversion than a reference sample, the mineral ilmenite. Generally, softer oxygen carriers were more porous and appeared to have a higher reactivity towards syngas. When compared with ilmenite, the conversion of $\mathrm{CO}$ was higher for all oxygen carriers and the conversion of $\mathrm{H}_{2}$ was higher when tested for longer reduction times. The oxygen carrier Sandvik 2 displayed the highest conversion of syngas and was therefore selected for solid fuel experiments. The conversion rate of solid fuels was higher with Sandvik 2 than with the reference sample, ilmenite.
} 


\section{NOTATION}

$\mathrm{CO}_{\text {,index }}$ Fraction of unconverted $\mathrm{CO}(-)(E q .16)$

$\mathrm{H}_{2}$,index Fraction of unconverted $\mathrm{H}_{2}(-)(E q .17)$

$M_{\mathrm{O}} \quad$ Molar mass of oxygen $\left(\mathrm{kg} \mathrm{mol}^{-1}\right)$

$m \quad$ Mass of the oxygen carrier $(\mathrm{kg})$

$m_{o x} \quad$ Mass of the oxygen carrier in its oxidized state $(\mathrm{kg})$

$m_{\text {red }} \quad$ Mass of the oxygen carrier in its reduced state $(\mathrm{kg})$

$m_{t} \quad$ Mass of carbon converted until time $t(\mathrm{~kg})$

$m_{t o t} \quad$ Total mass of carbon converted during reduction $(\mathrm{kg})$

$\dot{n}_{\text {out }} \quad$ Molar flux of the outgoing dry gas $\left(\mathrm{mol} \mathrm{s}^{-1}\right)$

$P_{\text {tot }} \quad$ Total pressure (bar)

$P_{i, \text { out }} \quad$ Partial pressure of component $i$ in the outgoing gas after steam condensation (bar)

$R_{\mathrm{O}} \quad$ Oxygen ratio (-)(Eq. 10)

$r_{\text {avg }} \quad$ Average rate of conversion for solid fuels $\left(\% \mathrm{~min}^{-1}\right)$ (Eq. 15)

$t \quad$ Time since the start of the reduction period with solid fuels (min)

$t_{0} \quad$ Time at the start of the reduction period (s)

$t_{1} \quad$ Time at the end of the reduction period (s)

$t_{X_{C}} \quad$ Time needed to reach a certain degree of carbon conversion (s)

$X_{C} \quad$ Degree of carbon conversion (-)(Eq. 14)

$y_{i, \text { out }} \quad$ Partial pressure of component $i$ in the outgoing gas before steam condensation (bar)

$\gamma_{\mathrm{CO}} \quad$ Gas yield of $\mathrm{CO}(-)(E q .7)$

$\gamma_{\mathrm{CO}, t o t}$ Total conversion of $\mathrm{CO}$ during a reduction period $(-)(E q .13)$

$\gamma_{\mathrm{H}_{2}} \quad$ Gas yield of $\mathrm{H}_{2}(-)(E q .8)$

$\omega \quad$ Mass-based oxygen-carrier conversion $(-)(E q .11)$

\section{INTRODUCTION}

The atmospheric $\mathrm{CO}_{2}$ concentration has increased by approximately $35 \%$ as compared with the pre-industrial level [1] and concern is growing about the effect of this on global climate. The drastic increase in $\mathrm{CO}_{2}$ concentration is primarily due to the intensified use of fossil fuels and the power generation sector is accountable for the largest share of global $\mathrm{CO}_{2}$ amounts released by human activities [2]. The apparent ways of addressing this issue are a transition from fossil fuels to renewable energy sources and making the use and conversion of energy more efficient. However, our large dependence on fossil fuels in combination with an increased global energy demand may make such a transition difficult to achieve in the foreseeable future. As a mid-term solution, carbon capture and storage of $\mathrm{CO}_{2}$ from combustion of fossil fuels may contribute to stabilizing the atmospheric $\mathrm{CO}_{2}$ concentration [3].

The basic idea of carbon capture and storage is to separate the $\mathrm{CO}_{2}$ produced from combustion of fossil fuels from the other flue gases and prevent it from reaching the atmosphere [4]. This can be achieved by storing the $\mathrm{CO}_{2}$ in geological formations, such as depleted oil and gas reservoirs or deep saline aquifers [5, 6]. Most processes for capturing $\mathrm{CO}_{2}$ from combustion in a power-production unit can be divided into three categories. These are post-combustion, pre-combustion and oxyfuel combustion [4]. Each of these include gas separation which adds significantly to costs and reduces energy efficiency. Another option, where active gas separation is not needed, is chemical looping combustion.

\section{CHEMICAL LOOPING COMBUSTION}

Chemical looping combustion is a novel technology intended for heat and power production with inherent $\mathrm{CO}_{2}$ separation. The basic concept of this technology was presented in a patent by Lewis and Gilliland in 1954 [7]. The technology was suggested as a method for capturing $\mathrm{CO}_{2}$ in power plants in order to reduce climate impact by Ishida and Jin in 1994 [8]. The total worldwide operational experience exceeds $4000 \mathrm{~h}$ in 12 different chemical looping combustion units [9]. In 2000, the first experiments with solid fuels were presented by Lyon and Cole [10] and the first continuously operated reactor system designed for converting solid fuels was demonstrated by Berguerand and Lyngfelt in 2008 [11].

The $\mathrm{CO}_{2}$ separation in chemical looping combustion is accomplished in an arrangement containing two interconnected reactors, a fuel reactor and an air reactor, as presented in Figure 1. Here, the combustion air fed into the air reactor is never mixed with the fuel fed into the fuel reactor. Instead, oxygen is transferred from the air reactor to the fuel reactor by circulating solid oxygen carriers. The most frequently used oxygen carriers are metal oxide particles, which are oxidized in the air reactor according to reaction (1) and reduced

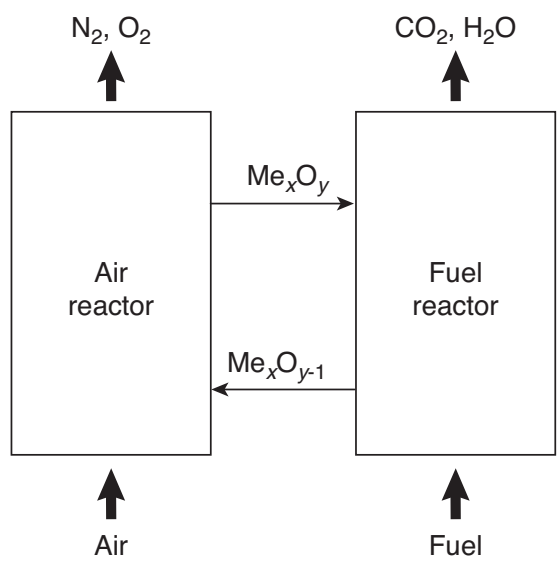

Figure 1

Schematic view of chemical looping combustion. 
in the fuel reactor according to reaction (2). From the fuel reactor, $\mathrm{CO}_{2}$ and $\mathrm{H}_{2} \mathrm{O}$ are obtained in a separate stream and almost pure $\mathrm{CO}_{2}$ can be obtained after steam condensation:

$$
\begin{gathered}
\mathrm{O}_{2}+2 \mathrm{Me}_{x} \mathrm{O}_{y-1} \leftrightarrow 2 \mathrm{Me}_{x} \mathrm{O}_{y} \\
\mathrm{C}_{n} \mathrm{H}_{2 m}+(2 n+m) \mathrm{Me}_{x} \mathrm{O}_{y} \leftrightarrow n \mathrm{CO}_{2}+m \mathrm{H}_{2} \mathrm{O}+(2 n+m) \mathrm{Me}_{x} \mathrm{O}_{y-1}
\end{gathered}
$$

The heat balance in the air and the fuel reactors is highly dependent on the selection and circulation of oxygen carriers and on the fuel used [12]. However, the total amount of heat evolved in the two reactors is identical to the heat from conventional combustion, where the fuel is oxidized by air; hence no extra energy is needed for the gas separation.

Although several design options for chemical looping combustion systems have been proposed, an arrangement based on two interconnected fluidized beds has some attractive features not attained by its alternatives. With fluidized beds, good contact between gas and solids is obtained and a significant flow of solid material, and thus oxygen, can be transferred between the two reactors [13]. Furthermore, this design adapts technology and components proven from other industrial applications such as circulating fluidized-bed boilers.

The main focus of research into chemical looping combustion has been on oxygen-carrier development, system analysis and reactor design for applications with gaseous fuels such as natural gas or methane. However, solid fuels are generally more abundant, less expensive, account for a larger share of global power generation and release more $\mathrm{CO}_{2}$ per unit of energy produced than gaseous fuels [14]. Therefore, the advantage of chemical looping combustion would be significantly increased if the technology could be adapted to convert solid fuels effectively.

When solid fuels are utilized, volatile gases are released from the fuel and converted according to reaction (2). The volatiles are released rapidly at high temperatures and, ideally, the solid fuel is fed in a way that allows good contact between volatiles and oxygen carriers to obtain a satisfactory conversion of these gases. Also, the remaining char needs to be gasified as the solid-solid reaction between char and oxygen carrier is not expected to progress at any significant rate. By fluidizing the fuel reactor with $\mathrm{H}_{2} \mathrm{O}$ and/or $\mathrm{CO}_{2}$, the char (C) will be gasified mainly to $\mathrm{H}_{2}$ and $\mathrm{CO}$ according to reactions (3) and/or (4) [15]. The char gasification rate with $\mathrm{H}_{2} \mathrm{O}$ is considerably higher than the rate with $\mathrm{CO}_{2}$ [16]. Hence, char gasification according to reaction (3) is preferred:

$$
\begin{gathered}
\mathrm{C}+\mathrm{H}_{2} \mathrm{O} \leftrightarrow \mathrm{CO}+\mathrm{H}_{2} \\
\mathrm{C}+\mathrm{CO}_{2} \leftrightarrow 2 \mathrm{CO}
\end{gathered}
$$

The gasification product, syngas containing mainly $\mathrm{CO}$ and $\mathrm{H}_{2}$ - if $\mathrm{H}_{2} \mathrm{O}$ is used for gasification - reacts with the oxygen carrier particles according to reactions (5) and (6):

$$
\begin{gathered}
\mathrm{Me}_{x} \mathrm{O}_{y}+\mathrm{CO} \leftrightarrow \mathrm{Me}_{x} \mathrm{O}_{y-1}+\mathrm{CO}_{2} \\
\mathrm{Me}_{x} \mathrm{O}_{y}+\mathrm{H}_{2} \leftrightarrow \mathrm{Me}_{x} \mathrm{O}_{y-1}+\mathrm{H}_{2} \mathrm{O}
\end{gathered}
$$

These reactions are generally very rapid and char gasification is therefore the rate-determining step when converting solid fuels in chemical looping combustion [17-19]. However, the gasification rate is considerably higher in chemical looping combustion when compared with traditional char gasification [19]. The reason for this is the removal of $\mathrm{CO}$ and $\mathrm{H}_{2}$ by reactions (5) and (6). The presence of $\mathrm{H}_{2}$ during the gasification of solid fuels is well known to inhibit the reaction rate $[20,21]$. This inhibiting effect of $\mathrm{H}_{2}$ has also been shown to strongly affect the conversion of char in the presence of oxygen-carrier particles in a laboratoryscale, fluidized-bed reactor [22].

\section{OXYGEN CARRIERS}

Selection of suitable oxygen carriers is a critical step in developing chemical looping combustion [23]. When chemical looping combustion is used for solid fuels, the lifetime of the oxygen carriers is expected to be shorter than with gaseous fuels. This is because ash may deactivate the oxygen carrier and some of the oxygen carrier may be lost during ash separation. Therefore, the use of a low-cost, environmentally benign, oxygen-carrier material is beneficial. Also, since the gasification of the solid fuel produces mainly $\mathrm{CO}$ and $\mathrm{H}_{2}$ [24], it may not be useful to employ oxygen carriers which are highly reactive towards $\mathrm{CH}_{4}$, the major component in natural gas. Oxygen carriers that have a high reactivity towards $\mathrm{CH}_{4}$, such as Ni-based oxygen carriers, are generally expensive and are likely to be better suited to gaseous fuel applications.

Of the metal oxides suggested and investigated as oxygen carriers for chemical looping combustion, Fe-based oxygen carriers have the advantage of being comparatively cheap, environmentally friendly and accessible in large quantities $[25,26]$. Most studies on Fe-based oxygen carriers have focused on particles manufactured from pure chemicals and stabilized by supporting materials. Shen et al. have used an iron-based oxygen carrier to convert biomass in a $10 \mathrm{~kW}_{\text {th }}$ combustor [27]. However, to further decrease the oxygencarrier cost when utilizing solid fuels, an option is to use natural minerals, such as iron ores, or by-products from other processes, such as oxide scales from the steel industry [28]. Leion et al. have concluded that such materials are good candidates for converting solid fuels in chemical looping combustion [21] and Xiao et al. have reported promising results using an iron ore to convert solid fuels in a fixed-bed reactor under pressurized conditions [26]. Moldenhauer has investigated the mineral ilmenite and an iron-based oxide scale, in a $300 \mathrm{~W}$ circulating chemical looping combustion unit fuelled by syngas, to improve the understanding of the lifetime behaviour and other basic characteristics of these oxygen carriers [29].

Ilmenite, $\mathrm{FeTiO}_{3}$, has been suggested as a capable oxygen carrier for combustion of solid fuels and investigated 
extensively. It has been used in a $10 \mathrm{~kW}_{\text {th }}$ chemical looping combustor [11] with solid fuels and its properties have been studied experimentally in the laboratory. Here, its reactivity towards $\mathrm{CH}_{4}$ and syngas, containing $\mathrm{CO}$ and $\mathrm{H}_{2}$, as well as its fluidization behaviour were investigated [30, 31]. Ilmenite has also been tested in a $120 \mathrm{~kW}$ chemical looping combustor fuelled by $\mathrm{H}_{2}$ [32] and structural changes of the material after successive reduction and oxidation periods have been determined [33]. Ilmenite is used as a reference in this work because it is well documented and has displayed reliable properties in chemical looping combustion with solid fuels.

\section{EXPERIMENTAL PROCEDURE}

The procedure included measuring important parameters for oxygen carriers in chemical looping combustion. Such parameters include the ability to convert fuel and to be reoxidized; chemical composition, including changes during reactions; morphological texture; and strength of the particles. A number of industrial iron-based materials and an iron ore were studied and compared with the ilmenite. Before the reactivity experiments, each oxygen carrier material was heated in air at $950^{\circ} \mathrm{C}$ for about $24 \mathrm{~h}$ to obtain a high degree of oxidation and then sieved into narrow size fractions.

\subsection{Laboratory Set-up}

\subsubsection{Gaseous Fuel Experiments}

The reactivity experiments were conducted in a fluidized-bed reactor of quartz placed in an electrically heated furnace. The length of the reactor was $870 \mathrm{~mm}$ and the inner diameter in the reaction zone was $22 \mathrm{~mm}$. The reactor had a porous quartz plate placed $370 \mathrm{~mm}$ from the bottom. The bed material, $3 \mathrm{~g}$ of oxygen carrier particles, sized $125-180 \mu \mathrm{m}$, mixed in $12 \mathrm{~g}$ of inert quartz of the same size, was placed on the porous plate and heated to the desired experimental temperature of $950^{\circ} \mathrm{C}$ in an inert atmosphere of $\mathrm{N}_{2}$. The temperature was measured $5 \mathrm{~mm}$ under and $25 \mathrm{~mm}$ above the porous plate with Pentronic $\mathrm{CrAl} / \mathrm{NiAl}$ thermocouples. A bed containing $20 \mathrm{wt} \%$ active oxygen carrier was used to obtain an incomplete fuel conversion and thus enable comparison between the different oxygen carriers.

The bed was fluidized by alternating reducing and oxidizing gases, thus simulating the cyclic conditions of a chemical looping combustion system. The oxygen carriers were reduced by syngas with a 1:1 volume-ratio of $\mathrm{CO}$ and $\mathrm{H}_{2}$ and oxidized by $5 \mathrm{vol} \%$ of $\mathrm{O}_{2}$ in $\mathrm{N}_{2}$. Syngas was used for the reduction since it is the main gasification product when a solid fuel is gasified by steam, as shown in reaction (3). The low $\mathrm{O}_{2}$ concentration was used to avoid a major temperature increase caused by the highly exothermic oxidation reaction. After each reaction period, inert $\mathrm{N}_{2}$ was fed into the reactor for $180 \mathrm{~s}$ to avoid mixing of reducing and oxidizing gases. All flows were $900 \mathrm{~mL} / \mathrm{min}$ when normalized to 1 bar and $0^{\circ} \mathrm{C}$. The amount of active oxygen carrier material corresponds to $17 \mathrm{~kg} / \mathrm{MW}_{\text {fuel }}$. The pressure drop over the reactor was measured by Honeywell pressure transducers at a frequency of $20 \mathrm{~Hz}$. From the pressure fluctuations obtained, it was possible to verify fluidization of the bed during the experiment. After passing through the reactor, the gas was led to an electric cooler where the water produced during the reduction period was condensed and removed. Thereafter, the gas was transported to a Rosemount NGA-2000 gas analyser, which measured the flow and the concentrations of $\mathrm{H}_{2}, \mathrm{CO}, \mathrm{CO}_{2}, \mathrm{CH}_{4}$ and $\mathrm{O}_{2}$. Figure 2 shows a schematic diagram of the reactivity experiments.

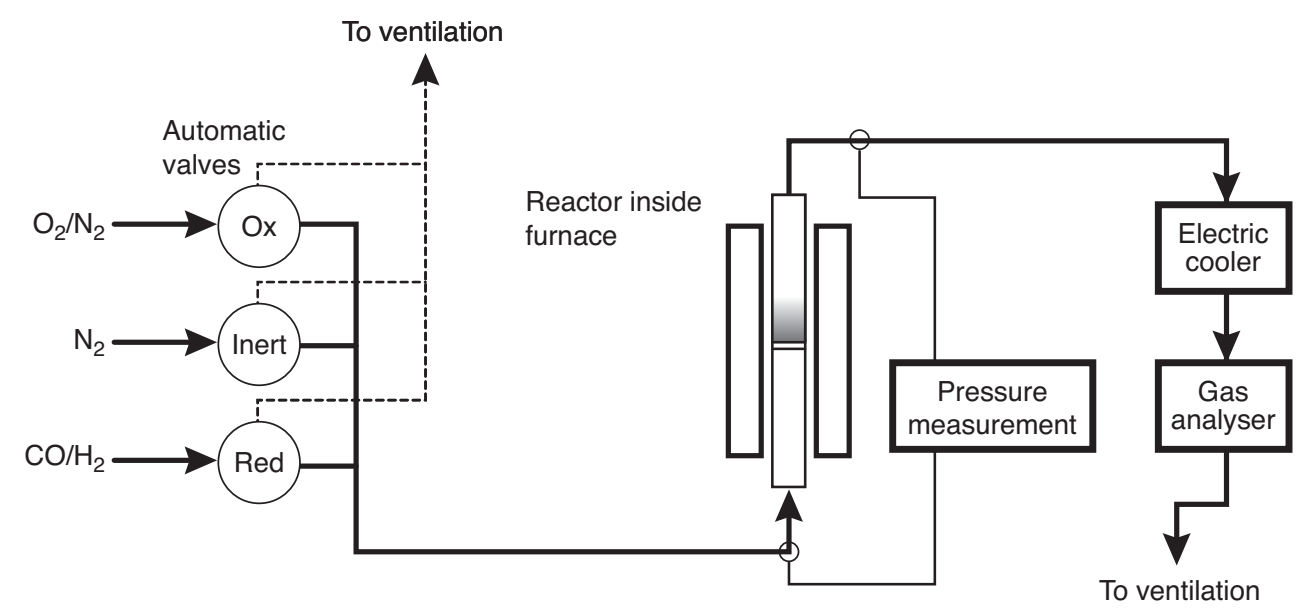

Figure 2

Experimental set-up of gaseous fuel experiments. 


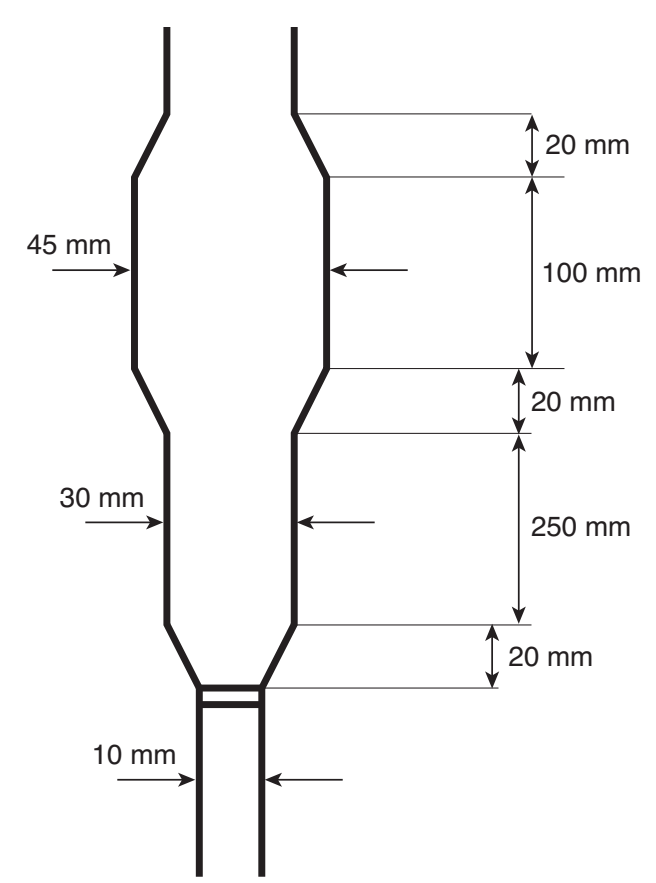

Figure 3

Fluidized-bed reactor for solid-fuel experiments.

\subsubsection{Solid-Fuel Experiments}

The set-up for the solid fuel experiments was somewhat different from that of the gaseous fuel experiments. The shape of the reactor, the amount of oxygen carrier, the feed of fuel, the experimental temperature and the gas flows used during the experiments were altered.

Instead of a straight quartz reactor, the solid fuel experiments were conducted in a reactor with a conical shape just above the porous quartz plate, as presented in Figure 3 . The conically shaped bed was used to improve the mixing of oxygen carrier and fuel particles. The wider diameter in the upper part of the reactor was constructed to avoid entrainment of fine particles. As this wider section is placed above the furnace, the temperature is also lower than in the lower part of the reactor. Hence, the gas velocity is significantly lower in the wider section.

The solid fuel, $0.2 \mathrm{~g}$ of particles in the size range of $125-180 \mu \mathrm{m}$ for each reduction period, was injected in the upper part of the reactor together with a $250 \mathrm{~mL}_{\mathrm{N}} / \mathrm{min}$ flow of $\mathrm{N}_{2}$. This inert flow was used partly to sweep the fuel particles down into the reactor and partly to serve as carrier gas after the steam had been removed in the electric cooler. The oxygen carrier and fuel particles were fluidized by 92 vol\% steam mixed with $\mathrm{N}_{2}$ during the reduction period and with $5 \mathrm{vol} \% \mathrm{O}_{2}$ diluted in $\mathrm{N}_{2}$ during oxidation. Thus, a high concentration of steam was used to gasify the fuel according to reaction (3). As in the gaseous fuel experiments, inert $\mathrm{N}_{2}$ was fed for $180 \mathrm{~s}$ between each reacting period to avoid mixing of the reacting gases. All flows entering in the bottom of the reactor were $600 \mathrm{~mL}_{\mathrm{N}} / \mathrm{min}$. For solid fuel experiments, $40 \mathrm{~g}$ of oxygen carrier were used and the experiments were conducted at a temperature of $970^{\circ} \mathrm{C}$.

Three solid fuels were investigated, a bituminous coal from El Cerrejon coal mine in Colombia, a Mexican petroleum coke and a Swedish wood char. The analyses of these fuels are presented in Table 1.

\subsection{Oxygen-Carrier Characterization}

In a full-scale, chemical looping combustion system, the oxygen carriers will be exposed to harsh conditions such as high temperatures and high gas velocities. As this may cause fragmentation and attrition of the particles, the oxygen-carrier particles require a certain strength. Therefore, the force needed to fracture the particles, the crushing strength, was measured for each oxygen carrier and is presented as an average of 30 crushed particles, sized 180-250 $\mu \mathrm{m}$.

The chemical compositions of the oxygen carriers were measured by Inductively Coupled Plasma-Optical Emission Spectrometry (ICP-OES) prior to the reactivity investigation. The phase-chemical compositions and particle morphologies of all fresh, heat-treated and tested materials were analysed using X-Ray Diffractometry (XRD) and Scanning Electron Microscopy (SEM) equipped with an Energy Dispersive $\mathrm{X}$-ray system (EDX).

\subsection{Data Evaluation}

In order to quantify the amount of converted $\mathrm{CO}$, a gas yield, $\gamma_{\mathrm{CO}}$, is defined as:

$$
\gamma_{\mathrm{CO}}=\frac{p_{\mathrm{CO}_{2}, \text { out }}}{p_{\mathrm{CO}_{2}, \text { out }}+p_{\mathrm{CO}, \text { out }}}
$$

TABLE 1

Analysis of solid fuels

\begin{tabular}{l|c|c|c|c|c|c|c|c|c|c}
\hline & $\begin{array}{c}\mathrm{HHV} \\
\mathrm{MJ} / \mathrm{kg})\end{array}$ & $\begin{array}{c}\text { Volatiles } \\
\text { (wt\%, dry ash free) }\end{array}$ & \multicolumn{3}{|c|}{$\begin{array}{c}\text { Proximate } \\
\text { (wt\%, as received) }\end{array}$} & \multicolumn{4}{c}{$\begin{array}{c}\text { Ultimate } \\
\text { (wt\%, dry ash free) }\end{array}$} \\
\hline & & & Moisture & Ash & Combustibles & $\mathrm{C}$ & $\mathrm{H}$ & $\mathrm{S}$ & $\mathrm{N}$ & $\mathrm{O}$ \\
\hline El Cerrejon coal & 25.9 & 40.9 & 6.2 & 11.9 & 81.9 & 83.0 & 5.1 & 0.8 & 1.9 & 9.2 \\
\hline Mexican petroleum coke & 31.7 & 10.9 & 8 & 0.5 & 91.5 & 88.8 & 3.1 & 6.6 & 1.0 & 0.5 \\
\hline Swedish wood char & - & 11.7 & 3 & 3 & 94 & - & - & - & - & - \\
\hline
\end{tabular}


Here, $p_{\mathrm{CO}_{2} \text {,out }}$ and $p_{\mathrm{CO}, \text { out }}$ are the partial pressures of $\mathrm{CO}_{2}$ and $\mathrm{CO}$ in the outgoing gas stream after steam condensation.

In a similar way, the conversion of $\mathrm{H}_{2}, \gamma_{\mathrm{H}_{2}}$, is defined as:

$$
\gamma_{\mathrm{H}_{2}}=\frac{y_{\mathrm{H}_{2} \mathrm{O}, \text { out }}}{y_{\mathrm{H}_{2} \mathrm{O}, \text { out }}+y_{\mathrm{H}_{2}, \text { out }}}
$$

Here, $y_{\mathrm{H}_{2} \mathrm{O} \text {,out }}$ and $y_{\mathrm{H}_{2} \text {,out }}$ are the partial pressures of $\mathrm{H}_{2} \mathrm{O}$ and $\mathrm{H}_{2}$ in the outgoing gas stream before steam condensation. The $\mathrm{H}_{2} \mathrm{O}$ is condensed in the electric cooler before reaching the analyser, and therefore not measured. However, as the partial pressure of $\mathrm{H}_{2}$ is equal to that of $\mathrm{CO}$ in incoming gas, it follows that the partial pressure of $\mathrm{H}_{2}$ plus $\mathrm{H}_{2} \mathrm{O}$ is equal to $\mathrm{CO}$ plus $\mathrm{CO}_{2}$. Hence, Equation (8) can be rewritten as:

$$
\gamma_{\mathrm{H}_{2}}=1-\frac{p_{\mathrm{H}_{2}, \text { out }}}{p_{\mathrm{CO}_{2}, \text { out }}+p_{\mathrm{CO}, \text { out }}}
$$

where $p_{\mathrm{H}_{2} \text {,out }}, p_{\mathrm{CO}_{2} \text {,out }}$ and $p_{\mathrm{CO} \text {, out }}$ are the partial pressures of $\mathrm{H}_{2}, \mathrm{CO}_{2}$ and $\mathrm{CO}$ in the outgoing gas stream after steam is removed.

The oxygen ratio shows the maximum mass flow of oxygen that can be transferred between the air and the fuel reactor for a given mass flow of circulating oxygen-carrier particles, and is defined as:

$$
R_{\mathrm{O}}=\frac{m_{o x}-m_{r e d}}{m_{o x}}
$$

where $m_{o x}$ is the mass of oxygen carrier when fully oxidized and $m_{\text {red }}$ is the mass of the fully reduced state.

The mass-based oxygen-carrier conversion is defined as:

$$
\omega=\frac{m}{m_{o x}}
$$

Here, $m$ denotes the mass of the oxygen carrier and $m_{o x}$ is the mass of the oxygen carrier in its most oxidized state. The mass-based conversion can be calculated as a function of time for the reducing period through

$$
\omega_{i}=\omega_{i-1}-\int_{t_{0}}^{t_{1}} \frac{M_{\mathrm{O}}}{m_{\text {ox }} P_{\text {tot }}} \dot{n}_{\text {out }}\left(2 p_{\mathrm{CO}_{2}, \text { out }}+p_{\mathrm{CO}, \text { out }}-p_{\mathrm{H}_{2}, \text { out }}\right) d t
$$

where $M_{\mathrm{O}}$ is the molar mass of oxygen, $\dot{n}_{\text {out }}$ is the molar flux of the outgoing dry gas, $t_{0}$ and $t_{1}$ are the times at the start and the end of the reduction period and $P_{t o t}$ is the total pressure.

To quantify the total conversion of $\mathrm{CO}$, the yield of $\mathrm{CO}$ during an entire reduction period is defined as:

$$
\gamma_{\mathrm{CO}, \text { tot }}=\frac{\int_{t_{0}}^{t_{1}} \dot{n}_{\text {out }} \cdot p_{\mathrm{CO}_{2}, \text { out }} d t}{\int_{t_{0}}^{t_{1}} \dot{n}_{\text {out }} \cdot\left(p_{\mathrm{CO}_{2}, \text { out }}+p_{\mathrm{CO}, \text { out }}\right) d t}
$$

The degree of carbon conversion for solid fuels is defined as:

$$
X_{\mathrm{C}}=\frac{m_{t}}{m_{t o t}}
$$

where $m_{t}$ is the mass of carbon converted until time $t$ and $m_{t o t}$ is the total mass of carbon converted during the reduction period. The average rate of conversion for solid fuels is defined as:

$$
r_{\text {avg }}=\frac{1}{t} \frac{m_{t}}{m_{\text {tot }}}
$$

where $t$ is the time elapsed since the start of the reduction period.

To quantify the fraction of unconverted $\mathrm{CO}$ and $\mathrm{H}_{2}$ leaving the reactor during solid fuel experiments, two indices are defined as:

$$
\mathrm{CO}_{\text {, index }}=\frac{\int_{t_{X_{C}=0.3}}^{t_{t_{C}=0.7}} \dot{n}_{\text {out }} \cdot p_{\mathrm{CO}, \text { out }} d t}{\int_{t_{X_{C}=0.3}}^{t_{X_{C}=0.7}} \dot{n}_{\text {out }}\left(p_{\mathrm{CO}_{2}, \text { out }}+p_{\mathrm{CO}, \text { out }}+p_{\mathrm{CH}_{4}, \text { out }}\right) d t}
$$

and:

$$
\mathrm{H}_{2, \text { index }}=\frac{\int_{t_{X_{C}=0.3}}^{t_{t_{C}=0.7}} \dot{n}_{\text {out }} \cdot p_{\mathrm{H}_{2}, \text { out }} d t}{\int_{t_{X_{C}=0.3}}^{t_{X_{C}=0.7}} \dot{n}_{\text {out }}\left(p_{\mathrm{CO}_{2}, \text { out }}+p_{\mathrm{CO}, \text { out }}+p_{\mathrm{CH}_{4}, \text { out }}\right) d t}
$$

where $t_{X_{C}}$ is the time needed to reach a certain degree of carbon conversion, $X_{\mathrm{C}}$. The boundary values of the degree of carbon conversion - i.e., $X_{\mathrm{C}}=0.3$ and $X_{\mathrm{C}}=0.7-$ are chosen as the rate of conversion is high and reasonably stable in this region. High conversion means higher concentrations and thus more reliable results.

\section{RESULTS AND DISCUSSION}

\subsection{Oxygen-Carrier Characterization}

Ten different low-cost, iron-based, oxygen-carrier materials were obtained from different suppliers. Seven of these were oxide scales, a by-product from the steel industry, four from Scana, two from Sandvik and one from ESAB. The other three were an industrial iron material from Höganäs, an unprocessed iron ore from LKAB and a product of vehicle recycling from Stena Metall.

The crushing strengths of these materials and the reference ilmenite, after the heat treatment, are listed in Table 2. The oxide scale from ESAB had a flake-like shape and therefore no crushing strength value could be obtained. All oxygen carriers tested are relatively hard and none of them can be excluded because of low mechanical strength. However, it 
TABLE 2

Crushing strength of the oxygen carriers

\begin{tabular}{c|c}
\hline Oxygen carrier material & Crushing strength (N) \\
\hline Scana 1 & 12.2 \\
\hline Scana 2 & 11.0 \\
\hline Scana 3 & 11.4 \\
\hline Scana 8 & 8.7 \\
\hline Sandvik 1 & 11.0 \\
\hline Sandvik 2 & 9.6 \\
\hline ESAB & - \\
\hline Stena metall & 3.6 \\
\hline Höganäs & 3.9 \\
\hline LKAB & 5.9 \\
\hline Ilmenite & 4.0 \\
\hline
\end{tabular}

should be noted that in a full-scale chemical looping combustion unit, the oxygen carriers are exposed to conditions that affect the attrition rate, e.g., high gas velocities in inlet nozzles and at cyclone walls. To determine the attrition, tests have to be conducted at appropriate temperatures and gas velocities where chemical reactions take place.

From XRD, $\mathrm{Fe}_{2} \mathrm{O}_{3}$ (hematite) was detected in all these materials after heat treatment. Some also contained $\mathrm{Fe}_{3} \mathrm{O}_{4}$ (magnetite) and in the Höganäs sample, both $\mathrm{FeO}$ (wüstite) and $\mathrm{Fe}$ were found. When fresh and heat-treated samples were compared, it was clearly seen that all oxygen carriers were oxidized during heat treatment although the oxidation was not complete for all of them. The phases identified in the ilmenite sample, after heat treatment, were $\mathrm{Fe}_{2} \mathrm{TiO}_{5}$ (pseudobrookite), $\mathrm{TiO}_{2}$ (rutile) and $\mathrm{Fe}_{2} \mathrm{O}_{3}$ (hematite).

Some interesting trends were observed when the surface texture of the oxygen carriers was studied with SEM. The oxide scales from Scana had a relatively smooth surface whereas other materials had an uneven, nodular surface texture after heat treatment, but prior to the reactivity experiments. Furthermore, the harder materials from Scana had a somewhat more compact texture while the softer materials showed a more porous surface texture. The same pattern was seen for the two oxide scales from Sandvik. From a comparison of the oxygen carriers after heat treatment with oxygen carriers after the reactivity experiments, it was found that some materials - e.g., the oxide scales from Scana - acquired a significantly more nodular surface texture after the experiments. Other materials, such as the iron ore from LKAB and the oxide scale from Sandvik, displayed similar textures before and after the experiments. The surface appearances of Scana 8, LKAB and Sandvik 2 before and after the reactivity experiments are compared in Figure 4.

The oxygen carriers contain varying levels of non-ferrous elements, as listed in Table 3. As each analysis is performed on an oxidized sample, after heat treatment, and the fraction of oxygen is not determined, the total amount is well below $100 \%$. The oxide scales from Scana and ESAB, the ore from LKAB and the industrial material from Höganäs contain very small amounts of non-ferrous elements while the oxide scales from Sandvik contain significant amounts of $\mathrm{Cr}$ and $\mathrm{Ni}$ and the material from Stena Metall contains a wide variety of

TABLE 3

Elemental analysis presented as wt $\%$ and $R_{\mathrm{O}}$-values for the oxygen carriers

\begin{tabular}{|c|c|c|c|c|c|c|c|c|c|c|}
\hline & Scana 1 & Scana 2 & Scana 3 & Scana 8 & Sandvik 1 & Sandvik 2 & ESAB & Stena Metall & Höganäs & LKAB \\
\hline $\mathrm{Fe}$ & 68 & 60 & 71 & 67 & 45 & 48 & 66 & 23 & 62 & 64 \\
\hline $\mathrm{Al}$ & $<0.04$ & 0.06 & 0.04 & $<0.04$ & $<0.04$ & $<0.04$ & $<0.04$ & 4.27 & 0.14 & 0.07 \\
\hline $\mathrm{Ba}$ & $<0.02$ & $<0.02$ & $<0.02$ & $<0.02$ & $<0.02$ & $<0.02$ & $<0.02$ & 0.28 & $<0.02$ & $<0.02$ \\
\hline $\mathrm{Ca}$ & 0.04 & 0.03 & 0.06 & 0.05 & $<0.02$ & $<0.02$ & $<0.02$ & 3.0 & 0.13 & 0.32 \\
\hline $\mathrm{Cr}$ & 0.76 & 0.22 & 0.17 & 0.69 & 3.7 & 4.0 & $<0.02$ & 0.11 & $<0.02$ & $<0.02$ \\
\hline $\mathrm{Cu}$ & 0.10 & 0.08 & 0.08 & 0.07 & 0.12 & 0.22 & $<0.02$ & 1.5 & $<0.02$ & $<0.02$ \\
\hline K & $<0.3$ & $<0.3$ & $<0.3$ & $<0.3$ & $<0.3$ & $<0.3$ & $<0.3$ & 1.7 & $<0.3$ & $<0.3$ \\
\hline $\mathrm{Mg}$ & 0.02 & 0.08 & $<0.02$ & 0.02 & $<0.02$ & $<0.02$ & $<0.02$ & 1.1 & 0.11 & 0.37 \\
\hline $\mathrm{Mn}$ & 0.45 & 0.43 & 0.50 & 0.98 & 0.98 & 1.0 & 0.36 & 0.43 & 0.03 & 0.10 \\
\hline $\mathrm{Na}$ & $<0.05$ & $<0.05$ & $<0.05$ & 0.10 & $<0.05$ & $<0.05$ & $<0.05$ & 1.4 & $<0.05$ & $<0.05$ \\
\hline $\mathrm{Ni}$ & 0.82 & 0.05 & 0.07 & 0.52 & 4.2 & 8.0 & $<0.02$ & 0.07 & $<0.02$ & 0.02 \\
\hline $\mathrm{Si}$ & 0.29 & 0.49 & 0.35 & 0.36 & 0.56 & 0.87 & 0.44 & 18 & 0.46 & 0.56 \\
\hline $\mathrm{Ti}$ & 0.05 & $<0.02$ & 0.02 & 0.02 & $<0.02$ & 0.37 & $<0.02$ & 0.56 & 0.16 & 0.15 \\
\hline $\mathrm{Zn}$ & $<0.01$ & $<0.01$ & $<0.01$ & $<0.01$ & 0.02 & 0.04 & $<0.01$ & 1.8 & $<0.01$ & $<0.01$ \\
\hline$R_{\mathrm{O}}(-)$ & 0.035 & 0.029 & 0.035 & 0.035 & 0.034 & 0.046 & 0.032 & 0.015 & 0.030 & 0.031 \\
\hline
\end{tabular}



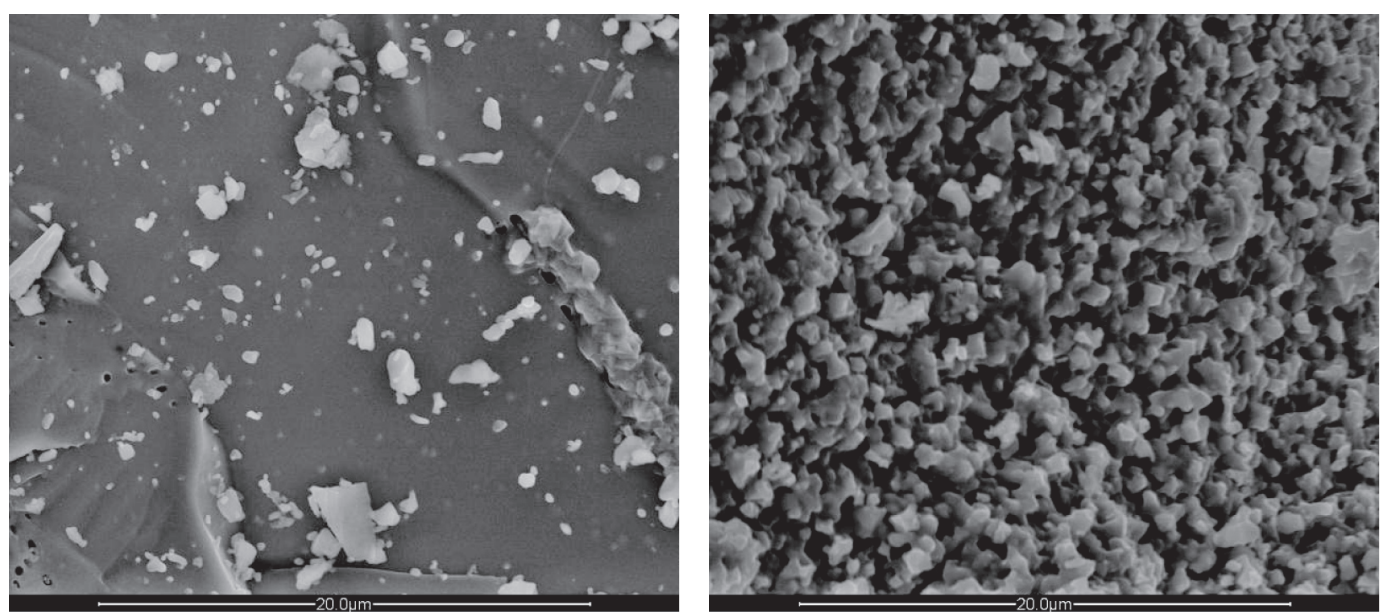

a)
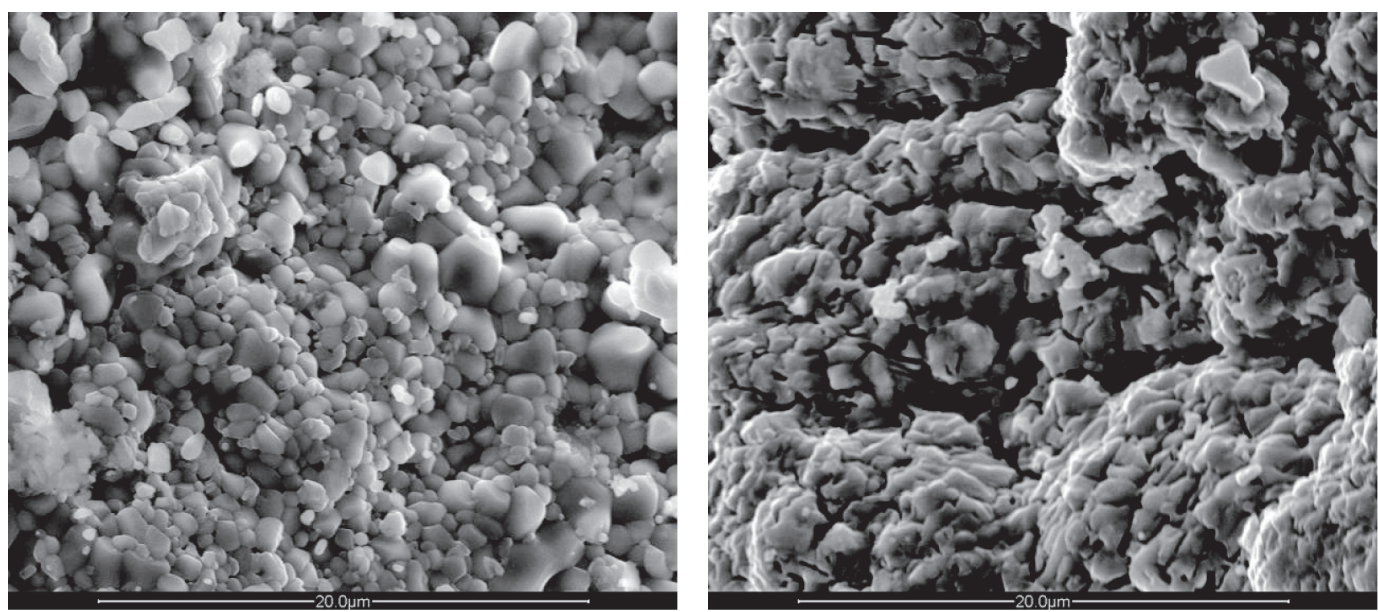

b)
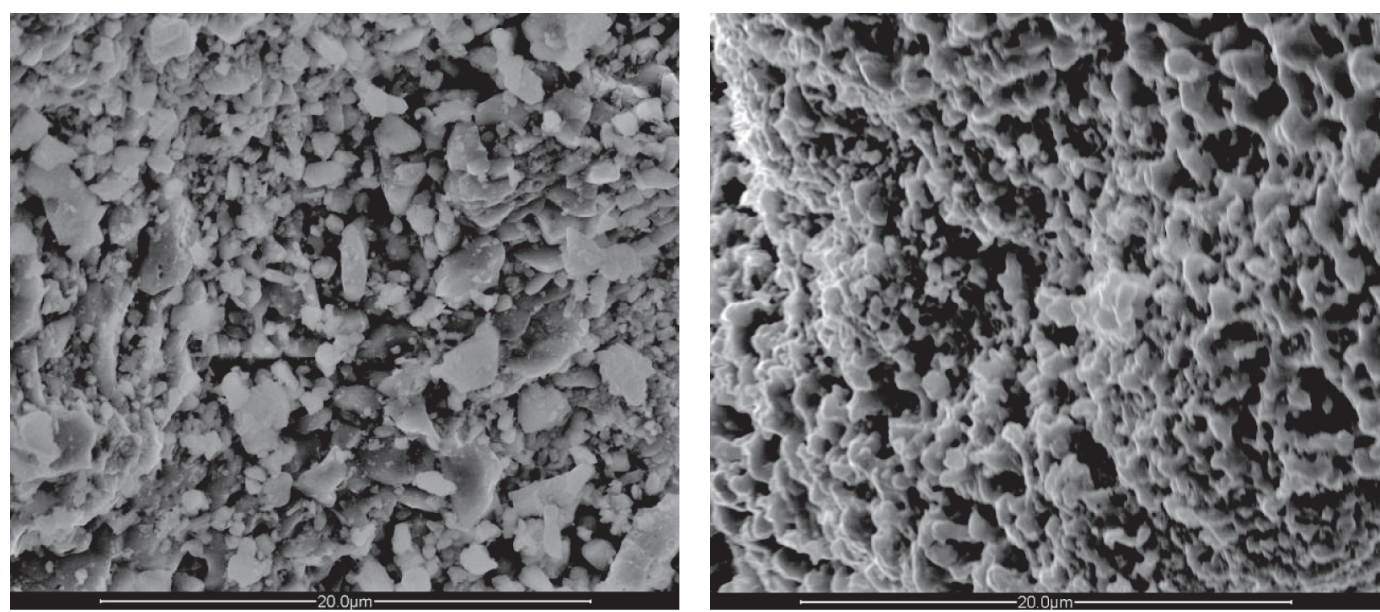

c)

Figure 4

Secondary-electron images of a) Scana 8, b) LKAB and c) Sandvik 2. On the left are images prior to testing, but after heat treatment, and on the right images after testing. The scale bar at bottom represents $20 \mu \mathrm{m}$. 

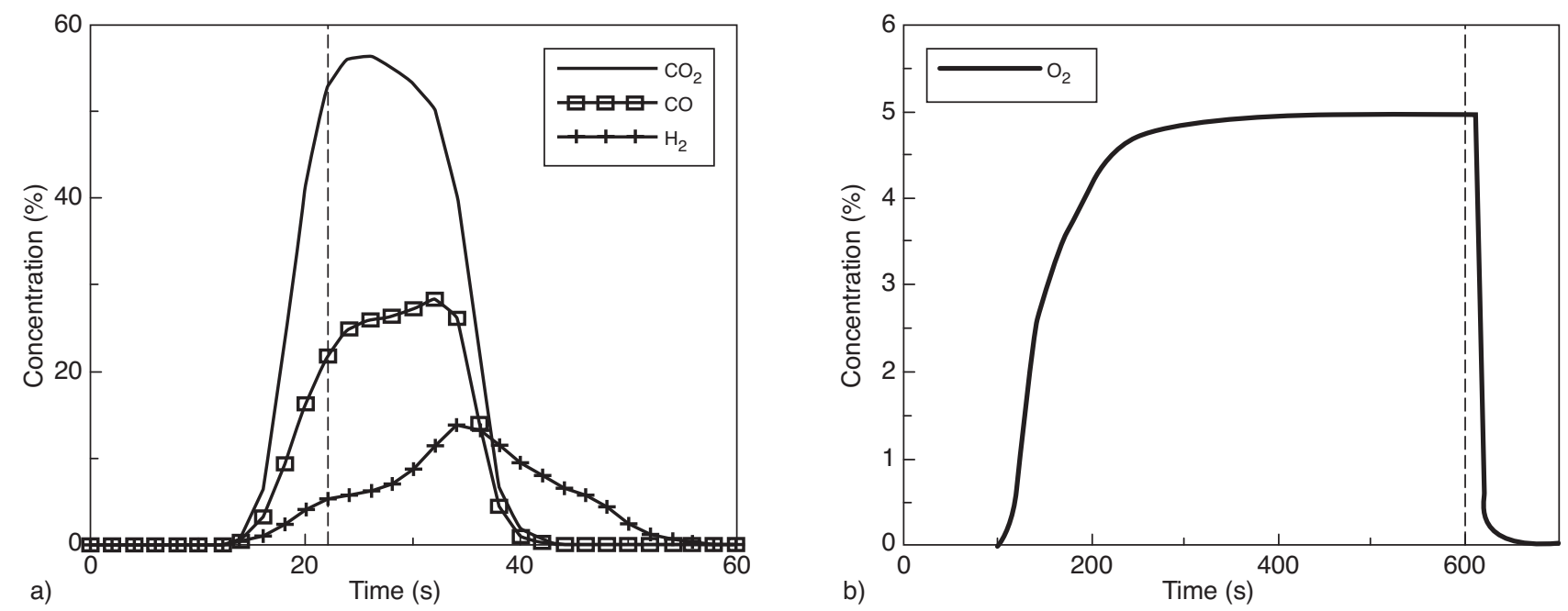

Figure 5

Outlet gas concentrations during a) reducing and b) oxidizing conditions for Sandvik 2. Vertical dashed lines indicate the end of the reaction period and transition to $\mathrm{N}_{2}$.

elements, including $\mathrm{Al}, \mathrm{Ca}, \mathrm{Cu}, \mathrm{K}, \mathrm{Mg}, \mathrm{Na}, \mathrm{Si}$ and $\mathrm{Zn}$. In the calculations of $R_{\mathrm{O}}$ it is assumed that $\mathrm{Fe}, \mathrm{Mn}, \mathrm{Cu}$ and $\mathrm{Ni}$ appear as oxides in the samples and that all other elements are inert, hence do not contribute to the fuel conversion. The oxidized and reduced forms of the active oxides are assumed to be $\mathrm{Fe}_{2} \mathrm{O}_{3} / \mathrm{Fe}_{3} \mathrm{O}_{4}, \mathrm{Mn}_{3} \mathrm{O}_{4} / \mathrm{MnO}, \mathrm{CuO} / \mathrm{Cu}$ and $\mathrm{NiO} / \mathrm{Ni}$. For pure $\mathrm{Fe}_{2} \mathrm{O}_{3} / \mathrm{Fe}_{3} \mathrm{O}_{4}, R_{\mathrm{O}}$ is 0.033 . Thus, it is not surprising that most of the samples have an $R_{\mathrm{O}}$ within the range 0.029-0.035, as seen in Table 3 . There are however two important exceptions, Stena Metall with an $R_{\mathrm{O}}$ of only $1.5 \%$ because of high concentrations of inert $\mathrm{Si}$ and $\mathrm{Al}$, and Sandvik 2 with an $R_{\mathrm{O}}$ of 4.6 because of a high content of $\mathrm{Ni}$.

\subsection{Reduction and Oxidation Behaviour}

Figure 5 shows the outlet gas concentration for one reduction and one oxidation period with Sandvik 2 as oxygen carrier and syngas as fuel. During oxygen-carrier reduction, the main part of the incoming $\mathrm{CO}$ and $\mathrm{H}_{2}$ is converted to $\mathrm{CO}_{2}$ and $\mathrm{H}_{2} \mathrm{O}$. However, as a result of the low oxygen carrier bed mass, there is always unreacted $\mathrm{CO}$ and $\mathrm{H}_{2}$ passing through the bed. As seen in Figure 5a, the retention time between the introduction of reacting gases and detection of product gases in the analyser is about $15 \mathrm{~s}$. The slope in the increase in $\mathrm{CO}_{2}$ is mainly caused by back-mixing in the gas path from the bed to the analyser, e.g., in the electric cooler. During oxygencarrier oxidation, complete conversion of the incoming oxygen occurs during the first $100 \mathrm{~s}$ for Sandvik 2, see Figure $5 \mathrm{~b}$. Hence, the oxidation is fast and limited by the supply of oxygen. The main focus will therefore be on the reduction of these oxygen carriers. The concentration profiles presented were typical for all oxygen carriers investigated, although the conversion of syngas varied with the material used. All oxygen carriers displayed complete conversion of the incoming $\mathrm{O}_{2}$ early in the oxidation periods.

\subsection{Effect of Cycle Number}

In a first set of reactivity experiments, all oxygen carriers were tested for a large number of short reductions followed by oxidations long enough to fully oxidize the samples. Short reduction periods were used to avoid the agglomerations that often occur with iron-based oxygen carriers at high extents of reduction [34]. During reduction, the mass-based conversion, $\omega$, decreased by about $1 \%$; i.e., oxygen corresponding to $1 \%$ of the total oxygen carrier mass was used to oxidize the fuel. Generally, the conversion of CO increased as a function of cycle number and cycles were continued until reasonably constant conversion was reached. Most oxygen carriers had good fluidization properties with the exception of the material from Höganäs where there was significant agglomeration. The reason for this might be that this material could not be fully oxidized during heat treatment and both $\mathrm{FeO}$ and $\mathrm{Fe}$ were detected by XRD in the heat treated sample. However, as the inert quartz fluidized throughout the experiment, the time when the agglomeration was formed could not be determined.

All of the investigated oxygen carriers converted between $40 \%$ and $80 \%$ of the incoming $\mathrm{CO}$ to $\mathrm{CO}_{2}$, which should be compared with ilmenite which converted only about $25 \%$ after reaching relatively stable gas conversion, as shown in Figure 6. 


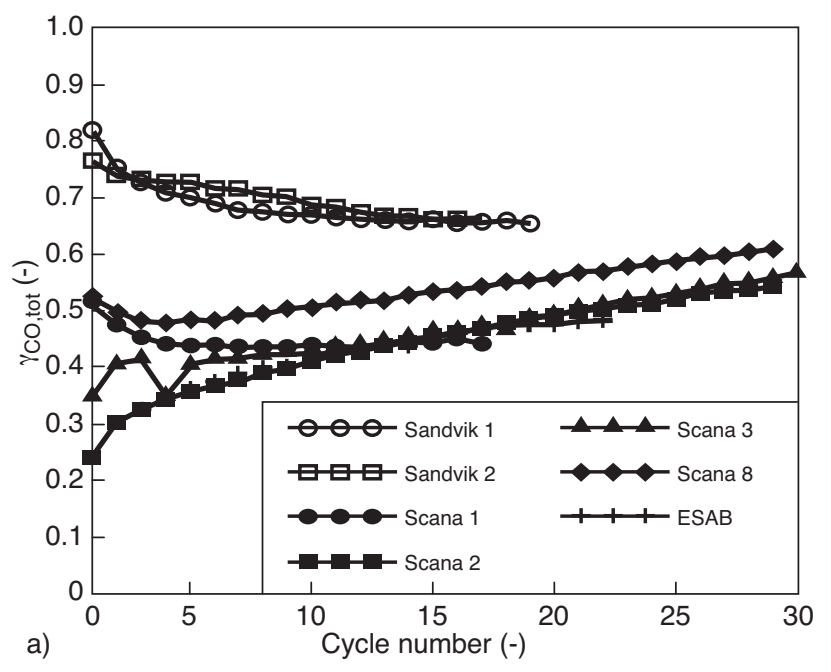

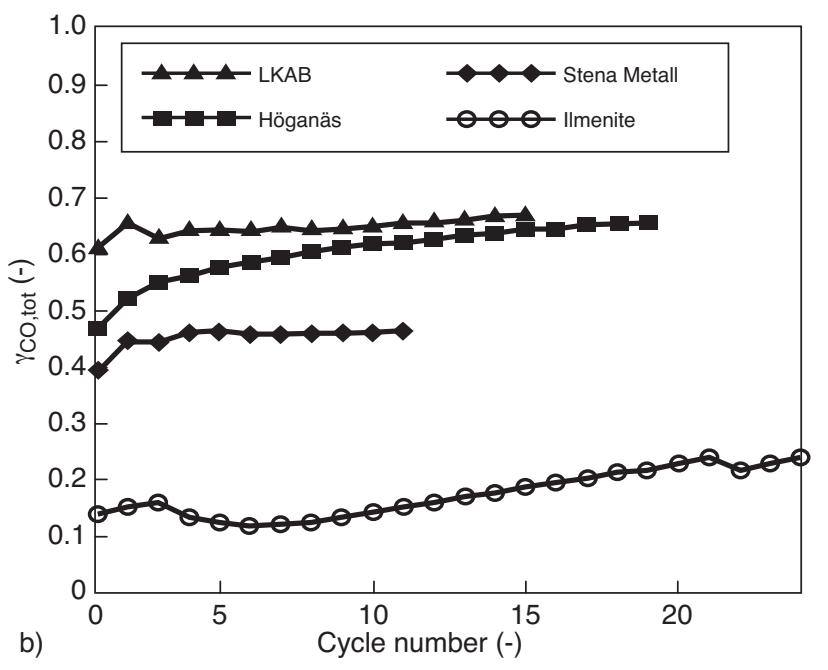

Figure 6

Total conversion of $\mathrm{CO}, \gamma_{\mathrm{CO}, t o t}$, during an entire reduction as a function of cycle number for a) the oxide scales and b) the other materials and the reference sample, ilmenite.

The conversion of $\mathrm{H}_{2}$ was considerably higher; all materials converted 90 to $96 \%$ of the incoming $\mathrm{H}_{2}$. The difference in $\mathrm{H}_{2}$ conversion between the different oxygen carriers was insignificant.

It has previously been shown that the conversion with ilmenite increases with increasing number of cycles [31, 33]. This activation is believed to be caused by a changed surface texture from a sharp-edged surface in fresh ilmenite to a nodular structure after activation [33]. This change in surface structure increases porosity and is therefore believed to improve gas-solid contact and hence reactivity. From SEM, a similar change in surface texture was seen for many of the oxygen carriers where the conversion of $\mathrm{CO}$ increased as number of cycles increased, e.g., Scana 8 shown in Figure 4a. Interestingly, for oxygen carriers where the conversion of $\mathrm{CO}$ was constant, or even decreased, with increasing number of cycles, these major structural changes were not observed, e.g., LKAB and Sandvik 2 shown in Figure $4 b, c$.

\subsection{Effect of Increased Reduction Time}

Based on the initial reactivity tests, three materials - the oxide scales Sandvik 2 and Scana 8 and the iron ore from LKAB - were selected as the most promising oxygen carriers. It should be mentioned that all oxide scales from the same supplier displayed similar properties, although the chosen materials had somewhat better fuel conversion than the other materials from these suppliers. This can be explained by the fact that these particles were softer, as indicated by the crushing strength values in Table 2, and more porous as seen in SEM. The ore from LKAB was chosen over the material from Stena Metall as it showed superior reactivity and higher strength. The sample from Höganäs was excluded as it agglomerated during the initial screening and the oxide scale from ESAB was not selected because of its flake-like geometry and the fact that it had a lower CO conversion than the best oxide scales from Sandvik and Scana.

In a second test series, Sandvik 2, Scana 8 and the iron ore from LKAB were compared with ilmenite in reactivity tests with increasing lengths of the reduction periods. Figure 7 shows the conversion of $\mathrm{CO}$ and $\mathrm{H}_{2}$ as a function of oxygencarrier conversion for these oxygen carriers when constant conversion has been reached, after 26-36 cycles. The dashed lines represent conversion of $\mathrm{H}_{2}$ and the solid lines the $\mathrm{CO}$ conversion.

The oxide scale from Sandvik has the highest conversion of $\mathrm{CO}$ and, together with the oxide scale from Scana, the highest conversion of $\mathrm{H}_{2}$. Ilmenite displays the lowest conversion for both these gases. The reason why the oxide scale from Sandvik is the most reactive may be due to higher levels of non-ferrous oxides. As shown in Table 3, Sandvik 2 contains significant amounts of $\mathrm{Ni}$ and $\mathrm{Cr}$ and the Ni content might explain the high gas conversion, since $\mathrm{Ni}$ acts as an oxygen carrier. Furthermore, Sandvik 2 contains small amounts of $\mathrm{Mn}$ and $\mathrm{Cu}$, species known to be capable oxygen carriers.

In both test series, ilmenite showed lower conversion than all other oxygen carriers. EDX indicated that the amount of 


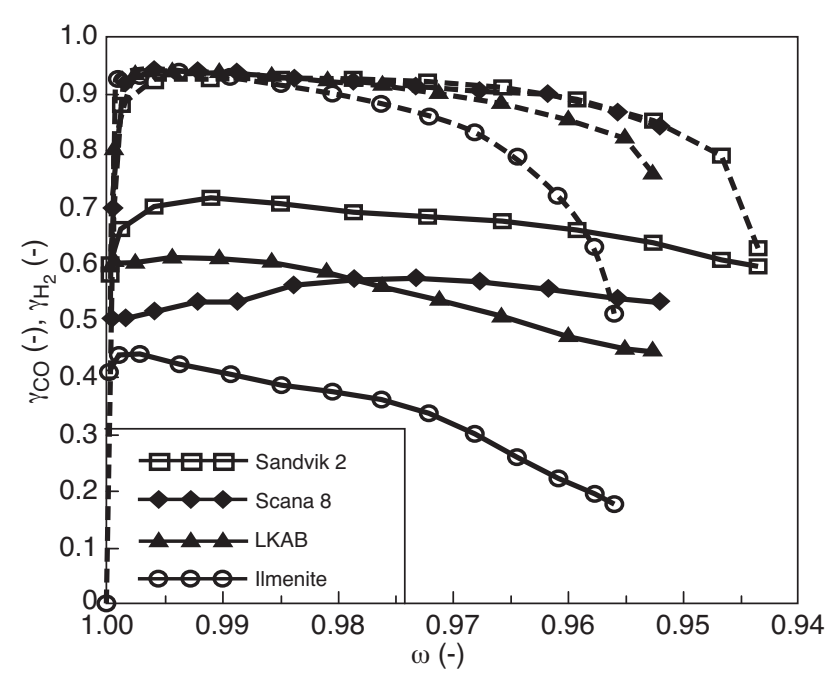

Figure 7

CO conversion, $\gamma_{\mathrm{CO}}$, solid lines, and $\mathrm{H}_{2}$ conversion, $\gamma_{\mathrm{H}_{2}}$, dashed lines, as a function of mass-based, oxygen-carrier conversion, $\omega$.

Fe was significantly higher than the amount of Ti near the surface of ilmenite particles after the second test series. This phenomenon was seen by Adánez et al. who detected formation of an external shell of free $\mathrm{Fe}_{2} \mathrm{O}_{3}$ (hematite) on ilmenite particles during reactivity experiments and an internal core containing $\mathrm{Fe}_{2} \mathrm{TiO}_{5}$ (pseudobrookite) and $\mathrm{TiO}_{2}$ (rutile), and therefore enriched in $\mathrm{TiO}_{2}$ [33].

\subsection{Solid-Fuel Experiments}

Figure 8 shows the outlet gas concentration, after steam condensation, as a function of time, for the reduction of Sandvik 2 with El Cerrejon coal, Mexican petroleum coke and Swedish wood char. Each fuel was tested for at least three consecutive cycles and no major differences in the outlet gas concentrations were observed as a function of cycle. Sandvik 2 was chosen for the solid-fuel experiments as it was the oxygen carrier with the highest conversion during the gaseous fuel experiments.

The oxidation behaviour was similar to the oxidation during gaseous fuel experiments, presented in Figure 5b, with initial complete conversion of the incoming $\mathrm{O}_{2}$. As there was no $\mathrm{CO}_{2}$ detected during this first part of the oxidation, all carbon appears to have been converted in the preceding reduction period. However, a small peak of $\mathrm{CO}_{2}$ was detected as oxygen started to pass unreacted through the bed. This $\mathrm{CO}_{2}$ is believed to be formed by oxidation of carbon stuck in the upper part of the reactor and in the fuel injection device.

Figure 8 shows that initial peaks of $\mathrm{CH}_{4}, \mathrm{CO}$ and $\mathrm{H}_{2}$ during reduction appeared with all fuels although the amount of $\mathrm{CO}$ and $\mathrm{H}_{2}$ was small when Mexican petroleum coke was used. These initial peaks are believed to be due to the pyrolysis of the fuel and reaction of volatiles with the oxygen-carrier particles, according to reaction (2). Back-mixing in the system causes substantial broadening of these peaks. By improving the contact between the volatiles and the oxygen carriers, for instance by injecting the fuel at the bottom of the bed, one can expect the conversion of these gases to improve greatly.

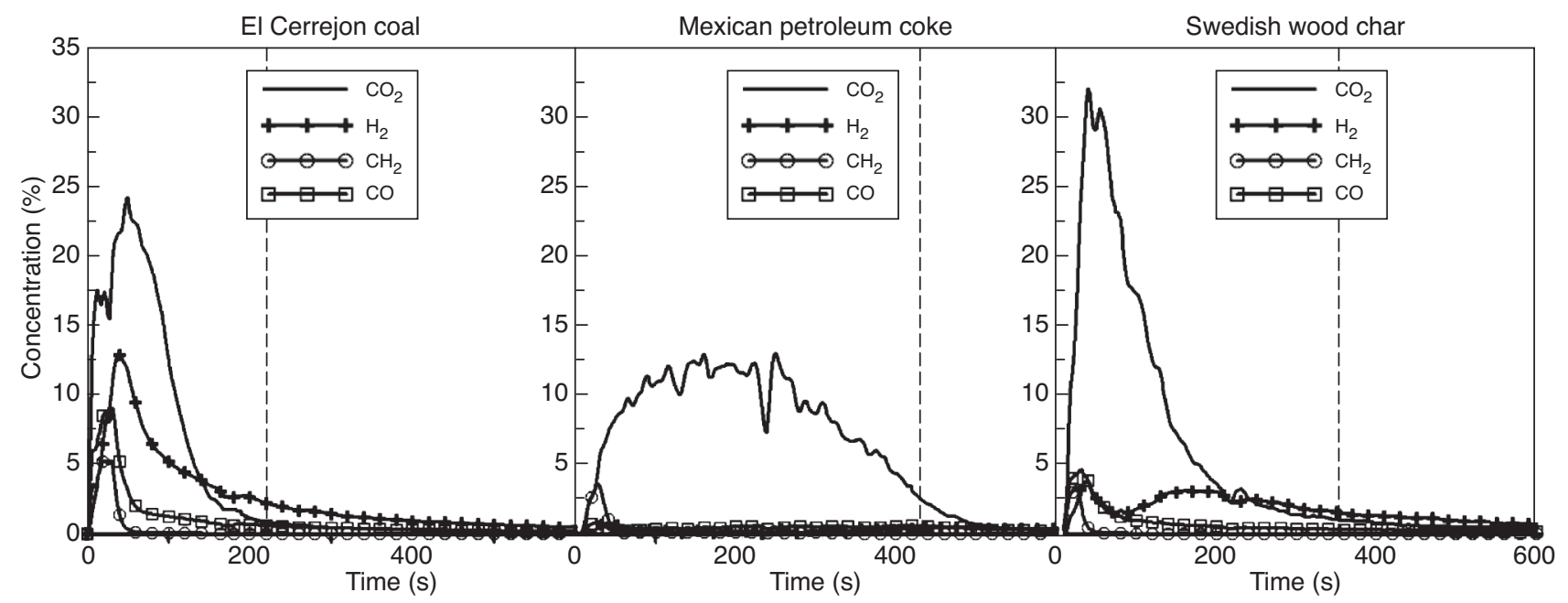

Figure 8

Outlet gas concentrations during reduction of Sandvik 2 with El Cerrejon coal, Mexican petroleum coke and Swedish wood char. Vertical dashed lines indicate the time to reach $95 \%$ conversion of each solid fuel. 
TABLE 4

Time and average rate to reach 95\% conversion of three solid fuels and $\mathrm{CO}$ and $\mathrm{H}_{2}$ indices for each fuel with Sandvik 2 and ilmenite as oxygen carriers

\begin{tabular}{|c|c|c|c|c|}
\hline & \multicolumn{4}{|c|}{ Sandvik 2} \\
\hline & $\begin{array}{l}\text { Time to convert } 95 \% \\
\text { of the fuel (min) }\end{array}$ & $\begin{array}{c}\text { Average rate, } r_{\text {avg }}, \text { to convert } \\
95 \% \text { of the fuel }(\% / \mathrm{min})\end{array}$ & $\mathrm{CO}_{\text {,index }}(\%)$ & $\mathrm{H}_{2, \text { index }}(\%)$ \\
\hline El Cerrejon coal & 3.7 & 25.9 & 14 & 39 \\
\hline Mexican petroleum coke & 7.2 & 13.3 & 4.1 & 1.8 \\
\hline \multirow[t]{3}{*}{ Swedish wood char } & 5.9 & 16.1 & 6.1 & 7.6 \\
\hline & \multicolumn{4}{|c|}{ Ilmenite } \\
\hline & $\begin{array}{l}\text { Time to convert } 95 \% \\
\text { of the fuel (min) }\end{array}$ & $\begin{array}{c}\text { Average rate, } r_{\text {avg }}, \text { to convert } \\
95 \% \text { of the fuel }(\% / \mathrm{min})\end{array}$ & $\mathrm{CO}_{\text {,index }}(\%)$ & $\mathrm{H}_{2, \text { index }}(\%)$ \\
\hline El Cerrejon coal & $5.9^{*}$ & $16.1^{*}$ & $21 *$ & $29 *$ \\
\hline Mexican petroleum coke & 10.8 & 8.8 & 4.6 & \\
\hline Swedish wood char & 6.3 & 15.1 & 15 & $20 *$ \\
\hline
\end{tabular}

* Denotes values calculated from experiments by Azimi [36].

The relatively long time needed for complete conversion of the fuel is a consequence of the slow gasification of the solid fuels, according to reaction (3), and the subsequent reactions of the intermediate gasification products with the oxygen carrier, according to reactions (5) and (6). Table 4 lists the time needed to convert $95 \%$ of each fuel, the average rate to reach this conversion, and the $\mathrm{CO}$ and $\mathrm{H}_{2}$ indices. The conversion time is based on the carbon-containing gases detected in the analyser; hence the losses of fuel during injection are not included. The values obtained with ilmenite as oxygen carrier, derived from tests conducted by Leion et al. [35] under the same conditions, are included for comparison. However, as these tests were conducted without on-line $\mathrm{H}_{2}$ measurements and with only Mexican petroleum coke and Swedish wood char as fuel, results from experiments by Azimi with El Cerrejon coal and $\mathrm{H}_{2}$,index for Swedish wood char have also been included [36].

Comparing the reactivities of Sandvik 2 and ilmenite, we see that the conversions of El Cerrejon coal and Mexican petroleum coke are significantly faster with Sandvik 2 and the conversion of Swedish wood char is somewhat faster with the oxide scale. Furthermore, the amount of CO released is lower with Sandvik 2 than it is with ilmenite for all fuels. The faster fuel conversion with Sandvik 2, compared with ilmenite, is likely to be associated with the higher reactivity of Sandvik 2, giving higher conversion of $\mathrm{H}_{2}$ to $\mathrm{H}_{2} \mathrm{O}$. This, in turn, reduces the inhibitory effect of $\mathrm{H}_{2}$ on char gasification.

The amount of $\mathrm{H}_{2}$ released is higher with Sandvik 2 than with ilmenite when El Cerrejon coal is used as fuel. However, with Swedish wood char, the amount released with ilmenite is significantly higher than the amount released with Sandvik 2. The reason why the $\mathrm{H}_{2}$, index is higher with Sandvik 2 than with ilmenite with El Cerrejon coal may be attributed to the very high fraction of volatiles in this fuel. As the solid fuel conversion is faster with Sandvik 2, a large fraction of the volatiles are released in the interval where the $\mathrm{H}_{2}$,index is calculated, hence the $\mathrm{H}_{2}$, index may be misleading for this fuel. Furthermore, the experiments by Azimi were conducted with somewhat larger fuel particles [36] which may have improved the mixing of fuel and oxygen-carrier particles; hence a larger fraction of the volatiles may have been converted inside the bed in these experiments.

\section{CONCLUSIONS}

Several low-cost, iron-based oxygen carriers with properties well suited for chemical looping combustion with solid fuels have been identified. These materials displayed a comparatively high fuel conversion and particle strength. The following points summarize the main findings:

- all oxygen carriers investigated produced higher conversions of $\mathrm{H}_{2}$ than of $\mathrm{CO}$;

- softer and more porous oxygen carriers appear to have a higher reactivity towards syngas;

- all oxygen carriers showed a higher conversion of CO than did the reference sample, ilmenite;

- all oxygen carriers tested at longer reduction times showed a higher conversion of $\mathrm{H}_{2}$ than did the ilmenite;

- of all the oxygen carriers, Sandvik 2 produced the highest conversion of syngas, likely due to the content of $\mathrm{Ni}, \mathrm{Cu}$ and $\mathrm{Mn}$; 
- the conversion rate of solid fuels was higher with Sandvik 2 than with the reference sample, ilmenite. The reason is likely to be the higher conversion of $\mathrm{H}_{2}$, which reduces the inhibitory effect of $\mathrm{H}_{2}$ on char gasification;

- in solid-fuel experiments, the amount of CO released was lower for Sandvik 2 than for ilmenite;

- for a solid fuel with low volatile content, the amount of $\mathrm{H}_{2}$ released was lower with Sandvik 2 than with ilmenite.

\section{ACKNOWLEDGMENTS}

This work was carried out within the emission-free chemical looping coal combustion process (ECLAIR) project (contract RFCP-CT-2008-00008) with a financial grant from the Research Fund for Coal and Steel of the European Community. Part of the experimental work was performed as a student bachelor project at Chalmers University of Technology.

\section{REFERENCES}

1 IPCC (2007) Changes in Atmospheric Constituents and in Radiative Forcing. Climate Change: The Physical Science Basis. Contribution of Working Group I to the Fourth Assessment Report of the Intergovernmental Panel on Climate Change.

2 IEA (2004) International Energy Agency; World Energy Outlook.

3 Azar C., Lindgren K., Larson E., Möllersten K. (2006) Carbon Capture and Storage from Fossil Fuels and Biomass - Costs and Potential Role in Stabilizing the Atmosphere, Climatic Change 74, 1-3, 47-79.

4 IPCC (2005) Special Report on Carbon Dioxide Capture and Storage.

5 Riddiford F., Wright I., Bishop C., Espie T., Tourqui A. (2005) Monitoring Geological Storage: the In Salah Gas $\mathrm{CO}_{2}$ Storage Project, Proceedings of the 7th International Conference on Greenhouse Gas Control Technologies 1353-1359.

6 Torp T.A., Gale J. (2004) Demonstrating Storage of $\mathrm{CO}_{2}$ in geological reservoirs: The Sleipner and SACS projects, Energy 29, 1361-1369.

7 Lewis W.K., Gilliland E.R. (1954) Production of Pure Carbon Dioxide, U.S. Patent No. 2665972.

8 Ishida M., Jin H. (1994) A New Advanced Power-Generation System using Chemical Looping Combustion, Energy 19, 4, 415-422.

9 Lyngfelt A. (2010) Oxygen Carriers for Chemical Looping Combustion - 4000 h of Operational Experience, Oil Gas Sci. Technol., to be published in a Special Issue: 1st International Conference on Chemical Looping.

10 Lyon R.K., Cole J.A. (2000) Unmixed Combustion: An Alternative to Fire, Combust. Flame 121, 249-261.

11 Berguerand N., Lyngfelt A. (2008) Design and Operation of a $10 \mathrm{~kW}_{\text {th }}$ Chemical Looping Combustor for Solid Fuels - Testing with South African Coal, Fuel 87, 12, 2713-2726.

12 Jerndal E., Mattisson T., Lyngfelt A. (2006) Thermal Analysis of Chemical Looping Combustion, Chem. Eng. Res. Des. 84, A9, 795-806.
13 Lyngfelt A., Leckner B., Mattisson T. (2001) A Fluidized-Bed Combustion Process with Inherent $\mathrm{CO}_{2}$ Separation; Application of Chemical Looping Combustion, Chem. Eng. Sci. 56, 10, 3101-3113.

14 IEA (2009) Key World Energy Statistics.

15 Berguerand N., Lyngfelt A. (2008) The Use of Petroleum Coke as Fuel in a $10 \mathrm{~kW}_{\text {th }}$ Chemical Looping Combustor, Int. J. Greenhouse Gas Control 2, 2, 169-179.

16 Roberts D.G., Harris D.J. (2007) Char Gasification in Mixtures of $\mathrm{CO}_{2}$ and $\mathrm{H}_{2} \mathrm{O}$ : Competition and Inhibition, Fuel 86, 17-18, 2672-2678.

17 Abad A., Garcia-Labiano F., de Diego L.F., Gayan P., Adanez J. (2007) Reduction Kinetics of $\mathrm{Cu}_{-}, \mathrm{Ni}_{-}$, and Fe-Based Oxygen Carriers Using Syngas $\left(\mathrm{CO}+\mathrm{H}_{2}\right)$ for Chemical Looping Combustion, Energ. Fuel. 21, 4, 1853-2843.

18 Dennis J.S., Scott S.A., Hayhurst A.N. (2006) In Situ Gasification of Coal using Steam with Chemical Looping: A Technique for Isolating $\mathrm{CO}_{2}$ from Burning a Solid Fuel, J. Energ. Institute 79, 3, 187-190.

19 Leion H., Mattisson T., Lyngfelt A. (2007) The Use of Petroleum Coke as Fuel in Chemical Looping Combustion, Fuel 86, 12-13, 1947-1958.

20 Lussier M.G., Zhang Z., Miller D.J. (1998) Characterizing Rate Inhibition in Steam/Hydrogen Gasification via Analysis of Adsorbed Hydrogen, Carbon 36, 9, 1361-1369.

21 Leion H., Jerndal E., Steenari B.-M., Hermansson S., Israelsson M., Jansson E., Johnsson M., Thunberg R., Vadenbo A., Mattisson T., Lyngfelt A. (2009) Solid Fuels in Chemical Looping Combustion using Oxide Scale and Unprocessed Iron Ore as Oxygen Carriers, Fuel 88, 10, 1945-1954.

22 Keller M., Leion H., Mattisson T., Lyngfelt A. (2010) Gasification Inhibition in Chemical Looping Combustion with Solid Fuels, submitted for publication.

23 Lyngfelt A., Johansson M., Mattisson T. (2008) Chemical Looping Combustion - Status of Development, 9th International Conference on Circulating Fluidized Beds, May 13-16, Hamburg, Germany.

24 Leion H., Mattisson T., Lyngfelt A. (2008) Solid Fuels in Chemical Looping Combustion, Int. J. Greenhouse Gas Control 2, 180-193.

25 Mattisson T., Lyngfelt A., Cho P. (2001) The Use of Iron Oxide as an Oxygen Carrier in Chemical Looping Combustion of Methane with Inherent Separation of $\mathrm{CO}_{2}$, Fuel 80, 13, 1953-1962.

26 Xiao R., Song Q., Zhang S., Zheng W., Yang Y. (2010) Pressurized Chemical Looping Combustion of Chinese Bituminous Coal: Cyclic Performance and Characterization of Iron Ore-Based Oxygen Carrier, Energ. Fuel. 24, 2, 1449-1463.

27 Shen L., Wu J., Xiao J., Song Q., Xiao R. (2009) Chemical Looping Combustion of Biomass in a $10 \mathrm{~kW}_{\text {th }}$ Reactor with Iron Oxide as an Oxygen Carrier, Energ. Fuel. 23, 5, 2498-2505.

28 Leion H., Mattisson T., Lyngfelt A. (2009) Use of Ores and Industrial Products As Oxygen Carriers in Chemical Looping Combustion, Energ. Fuel. 23, 4, 2307-2315.

29 Moldenhauer P. (2009) Testing of Minerals and Industrial ByProducts as Oxygen Carriers for Chemical Looping Combustion in a $300 \mathrm{~W}$ Test Reactor, MSc Thesis, Chalmers University of Technology, T2009-325.

30 Azis M.M., Jerndal E., Leion H., Mattisson T., Lyngfelt A. (2010) On the Evaluation of Synthetic and Natural Ilmenite Using Syngas as Fuel in Chemical Looping Combustion (in press). 
31 Leion H., Lyngfelt A., Johansson M., Jerndal, E., Mattisson T. (2008) The Use of Ilmenite as an Oxygen Carrier in Chemical Looping Combustion, Chem. Eng. Res. Des. 86, 9, 1017-1026.

32 Kolbitsch P., Pröll T., Bolhar-Nordenkampf J., Hofbauer H. (2009) Operating Experience with Chemical Looping Combustion in a $120 \mathrm{~kW}$ Dual Circulating Fluidized Bed (DCFB) Unit, Energy Procedia 1, 1, 1465-1472.

33 Adanez J., Cuadrat A., Abad A., Gayan P., de Diego L.F. (2010) Ilmenite Activation during Consecutive Redox Cycles in Chemical Looping Combustion, Energ. Fuel. 24, 2, 1402-1413.

34 Cho P., Mattisson T., Lyngfelt A. (2006) Defluidization Conditions for Fluidized-Bed of Iron, Nickel, and Manganese oxide-Containing Oxygen-Carriers for Chemical Looping Combustion, Ind.Eng. Chem. Res. 45, 3, 968-977.
35 Leion H., Mattisson T., Lyngfelt A. (2008) $\mathrm{CO}_{2}$ Capture from Direct Combustion of Solid Fuels with Chemical Looping Combustion, Proceedings of the 33rd International Technical Conference on Coal Utilization \& Fuel Systems 1, 221-232.

36 Azimi G. (2010) Experimental Evaluation and Modelling of Steam Gasification and Hydrogen Inhibition in CLC with Solid Fuel, MSc Thesis, Chalmers University of Technology.

Final manuscript received in September 2010 Published online in March 2011 